\title{
OPTIMALISASI TES KOMET UNTUK PENENTUAN TINGKAT KERUSAKAN DNA AKIBAT PAPARAN RADIASI PENGION
}

\author{
Dwi Ramadhani, Devita Tetriana dan Viria Agesti Suvifan
}

Pusat Teknologi Keselamatan dan Metrologi Radiasi (PTKMR), BATAN

Jl. Lebak Bulus Raya No.49, Kotak Pos 7043 JKSKL Jakarta Selatan 12070

Tel (021) 7513906/ 7659511 Fax (021) 7657950

Email : dhani02@batan.go.id

Diterima: 29-02-2016

Diterima dalam bentuk revisi: 11-03-2016

Disetujui: 15-03-2016

\begin{abstract}
ABSTRAK
OPTIMALISASI TES KOMET UNTUK PENENTUAN TINGKAT KERUSAKAN DNA AKIBAT PAPARAN RADIASI PENGION. Tes komet dapat digunakan untuk mengukur tingkat kerusakan asam deoksiribonukleat (DNA) pada sel limfosit darah tepi akibat paparan radiasi pengion.Prinsip dasar dari tes komet adalah berdasarkan besarnya fragmen DNA terdenaturasi yang bermigrasi keluar dari inti sel selama proses elektroforesis. Terdapat beberapa aspek yang harus diperhatikan saat melakukan tes komet antara lain adalah konsentrasi agarose yang digunakan, waktu inkubasi pada alkali, kondisi elektroforesis (waktu, temperatur serta gradien voltase yang digunakan), serta parameter yang digunakan dalam analisis. Parameter yang sangat disarankan dalam menganalisis citra komet adalah persentase DNA ekor (\% DNA ekor). Persentase DNA ekor dapat dikonversi menjadi frekuensi lesion per $10^{6}$ pasangan basa (bp) DNA dengan menggunakan kurva yang menggambarkan hubungan antara dosis radiasi pengion dengan besarnya \% DNA ekor. Untuk mendapatkan hasil analisis tes komet yang akurat perlu dilakukan pembuatan kurva kalibrasi yang menggambarkan hubungan antara dosis radiasi pengion dengan besarnya \% DNA ekor. Analisis citra komet sebaiknya dilakukan dengan menggunakan perangkat lunak pengolahan citra sehingga dapat meningkatkan akurasi dan presisi serta mengurangi subjektivitas dalam menganalisis citra komet.
\end{abstract}

Kata kunci: asam deoksiribonukleat (DNA), radiasi pengion, tes komet.

\section{ABSTRACT}

COMET ASSAY OPTIMIZATION FOR ASSESSMENT OF DNA DAMAGE DUE TO RADIATION EXPOSURE. Comet assay can be used to measure the deoxyribonucleic acid (DNA) damage level caused by ionizing radiation exposure in peripheral blood lymphocytes. The principle of the comet assay is based on the amount of denatured DNA fragments that migrated out of the cell nucleus during electrophoresis. There are several aspects that must be concerned when doing the comet assay. For example the agarose concentration, duration of alkaline incubation, electrophoresis conditions (time, temperature, and voltage gradient), and the measurement parameters that used in analyze the comet. Percentage of DNA in the comet tail (\% tail DNA) is strongly recommended as a parameter when analyze the comet because it can be converted to lesions per $10^{6}$ base pairs (bp) using calibration curve that show relationship between the dose of ionizing radiation and \% tail DNA. To obtain an accurate result, the calibration curve must be made and comet should be analyzing using image processing analysis software since it can be increase the precision and reduce the subjectivity of the measurement process.

Keywords: comet assay, deoxyribonucleic acid (DNA), ionizing radiation. 


\section{PENDAHULUAN}

Setiap hari manusia selalu terpapar radiasi baik dari alam maupun saat melakukan pekerjaan sebagai pekerja radiasi. Radiasi alam dapat berupa radiasi kosmik dan radiasi terestrial (berasal dari radionuklida primordial dikerak bumi) (1). Paparan radiasi pengion dapat menyebabkan kerusakan pada materi genetik yaitu asam deoksiribonukleat (DNA) (2). Kerusakan tersebut dapat berupa putusnya salah satu untai DNA (single strand break / SSB) dan putusnya kedua untai DNA pada posisi yang berhadapan (double strand breaks / DSB). Kerusakan DNA akibat paparan radiasi pengion dapat dideteksi dengan menggunakan tes komet (Comet Assay). Prinsip analisis tes komet adalah berdasarkan besarnya fragmen DNA terdenaturasi yang bermigrasi keluar dari inti sel selama proses elektroforesis $(3,4)$. Elektroforesis adalah teknik pemisahan komponen atau molekul bermuatan berdasarkan perbedaan tingkat migrasinya pada media gel agarose (5).

Secara singkat tes komet dilakukan dengan menanamkan (embedding) sel pada lapisan tipis low melting agarose (LMA) di atas preparat mikroskop terlebih dahulu. Pelisisan sel kemudian dilakukan dengan menggunakan larutan deterjen serta garam konsentrasi tinggi. Selanjutnya dilakukan penghilangan protein dan histon sehingga nukleolus sel berada pada rongga-rongga LMA $(6,7)$. Untai ganda DNA secara umum memiliki struktur terpilin yang sangat kompak (supercoiling), namun struktur tersebut sedikit mengendur pada sekitar daerah DSB DNA. Molekul DNA mengandung gugus fosfat bermuatan listrik negatif saat berada pada larutan alkali, sehingga daerah pada untai ganda DNA yang mengalami pengenduran dan mengandung DSB akan bermigrasi menuju kutub positif (anoda) saat elektroforesis. Migrasi tersebut akan membentuk ekor komet, sedangkan daerah yang tidak mengalami pengenduran akan membentuk kepala komet (Gambar 1) (7). Komet yang terbentuk kemudian diwarnai dengan pewarna fluorescent atau pewarna perak. Pewarna yang banyak digunakan adalah ethidium bromide, propidium iodide dan 4,6-diamidino-2-phenylindole (DAPI).

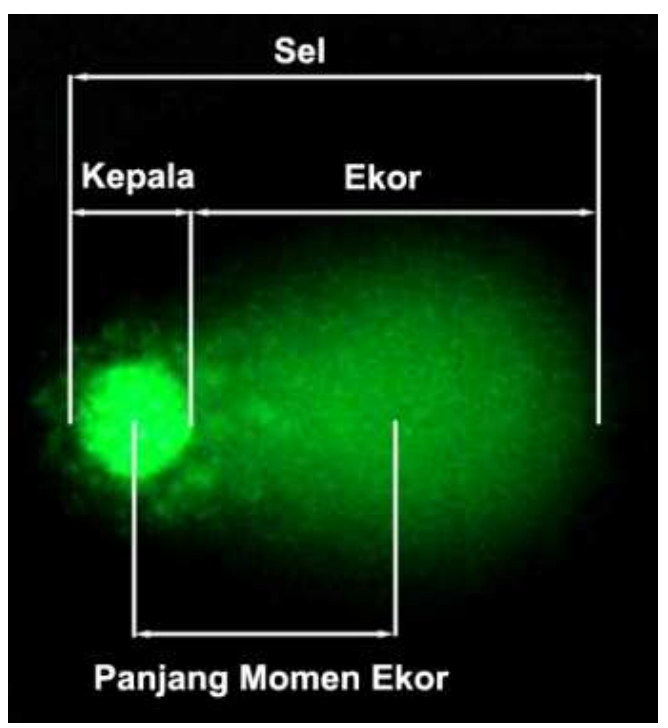

Gambar 1. Citra hasil tes komet (8).

Citra hasil tes komet dapat dianalisis secara manual atau menggunakan perangkat lunak pengolahan citra digital. Jumlah minimal yang harus diamati pada suatu penelitian dengan menggunakan tes komet adalah sebanyak 50 komet dari tiap preparat (9). Tes komet dapat digunakan untuk mengukur tingkat kerusakan DNA pada sel 
limfosit darah tepi. Beberapa metode dapat digunakan untuk pengoptimalan tes komet sehingga dapat diketahui secara pasti besarnya kerusakan DNA akibat paparan radiasi akan dibahas dalam makalah.

\section{ANALISIS CITRA KOMET}

Analisis citra komet dapat dilakukan dengan dua cara. Pertama secara manual dan dilakukan langsung menggunakan mikroskop fluorescent. Analisis secara manual dilakukan dengan membagi citra komet kedalam lima tingkatan (0 sampai 4) berdasarkan kerusakan DNA yang teramati (Gambar 2) (10,11). Meskipun mudah untuk dilakukan analisis secara manual tidaklah sederhana. Oleh karena itu analisis menggunakan perangkat lunak pengolahan citra digital lebih banyak digunakan meskipun analisis secara manual masih dilakukan. Analisis citra komet dengan menggunakan perangkat lunak pengolahan citra digital dapat meningkatkan akurasi dan presisi serta mengurangi subjektivitas dalam menganalisis citra komet $(12,13)$.

Hingga kini terdapat beberapa pe- rangkat lunak pengolahan citra untuk menganalisis citra digital komet baik yang bersifat terbuka (opensource) maupun komersial (licence). Sebagai contoh Helma et al. pada tahun 2000 membuat bahasa macro pada perangkat lunak pengolahan citra yaitu $\mathrm{NIH}$ Image untuk menganalisis citra komet. Sayangnya NIH Image hanya dapat digunakan pada komputer dengan sistem operasi Macintosh (14). NIH Image adalah perangkat lunak pengolahan citra yang dikembangkan oleh Wayne Rasband dan kini telah digantikan oleh ImageJ. ImageJ dikembangkan dalam bahasa Java sehingga kini dapat digunakan pada semua sistem operasi komputer (14). ImageJ menyediakan fasilitas pembuatan macro untuk dapat digunakan dalam mengolah citra digital komet. Macro adalah baris-baris kode pemrograman yang berisi perintah untuk menentukan masukan dan keluaran dalam bahasa pemrograman tertentu $(15,16)$.
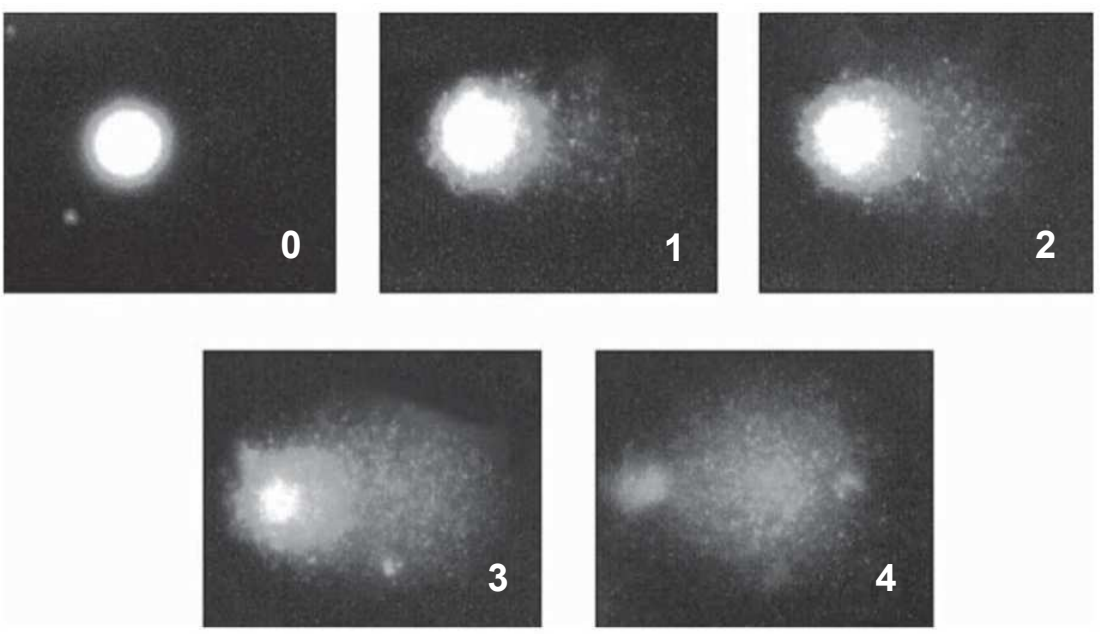

Gambar 2. Lima tingkat kerusakan DNA yang tervisualisasikan pada teskomet(9). 
Konca et al. pada tahun 2003 membuat perangkat lunak yang dapat digunakan secara bebas untuk menganalisis citra digital komet yaitu CASPLab Comet Assay (17). CASPLab dikembangkan menggunakan FOX library (http://www.fox-toolkit.org/) sehingga dapat dijalankan pada hampir seluruh sistem operasi komputer baik Windows maupun Linux. CASPLab dapat diunduh pada situs http://casplab.com/ (18). CASPLab hanya dapat digunakan pada citra digital komet hasil tes komet dengan pewarna berpendar (fluorescent). Apabila pewarna komet adalah pewarna perak maka harus terlebih dahulu menjadi citra negatif untuk dapat diolah menggunakan CASPLab Comet Assay (17). Perangkat lunak pengolahan citra digital dapat digunakan untuk mengukur beberapa parameter dari citra digital komet. Beberapa parameter tersebut antara lain adalah sebagai berikut (12).

1. DNA Kepala Komet (Head DNA) yaitu menunjukkan banyaknya DNA pada kepala komet

2. DNA Ekor Komet (Tail DNA) yaitu menunjukkan banyaknya DNA pada ekor komet

3. Persentase DNA Kepala Komet (\% head $D N A)$ yaitu menunjukkan persentase DNA pada kepala komet

4. Persentase DNA Ekor Komet (\% tail $D N A)$ yaitu menunjukkan persentase DNA pada ekor komet

5. Radius Kepala Komet (Head radius) yaitu menunjukkan radius pada kepala komet

6. Panjang Ekor Komet (Tail length) yaitu menunjukkan panjang ekor komet yang diukur dari batas paling kanan kepala komet hingga ujung ekor komet

7. Panjang Komet (Comet length) yaitu menunjukkan panjang komet keseluruhan mulai dari batas paling kiri kepala komet hingga ujung ekor komet

8. CoG Kepala (Head CoG) yaitu menunjukkan "Centre of gravity" dari DNA pada kepala komet

9. CoG Ekor (Tail CoG) yaitu menunjukkan "Centre of gravity" dari DNA pada ekor komet

10. Momen Ekor (Tail moment) yaitu menunjukkan panjang dari CoG kepala hingga CoG ekor

11. Momen ekor Olive (Olive tail moment) adalah hasil dari perkalian persentase DNA pada ekor komet dengan nilai hasil pengurangan antara CoG ekor dengan CoG kepala.

Tiga parameter yaitu persentase DNA ekor (\% $\mathrm{T})$, panjang ekor dan momen ekor adalah parameter yang paling umum digunakan dalam menganalisis citra komet. Persentase DNA ekor merupakan parameter yang sangat disarankan dalam menganalisis citra komet. Hal tersebut dikarenakan \% T dapat diekspresikan dalam skala nominal mulai dari 0 hingga $100 \%$. Dengan demikian komparasi antara hasil penelitian yang menggunakan tes komet dapat dilakukan. Kondisi elektroforesis dalam penelitian dengan menggunakan tes komet harus diatur sedemikian rupa sehingga sel pada kelompok kontrol atau tanpa perlakuan tetap menunjukkan proses migrasi DNA dengan nilai \% T sebesar 5 hingga 10 (19).

Analisis citra komet secara manual sebaiknya dilakukan pada sebanyak 100 citra komet. Dengan demikian nilai yang 
(Dwi Ramadhani)

diperoleh berada dalam kisaran 0 sampai 400. Satuan yang umum digunakan dalam analisis manual adalah "arbitrary units" (au). Nilai tersebut dapat dikonversikan menjadi 0 hingga 100 au dengan membagi empat nilai hasil analisis manual dari sebanyak 100 citra komet. Hal tersebut dilakukan agar nilai au yang diperoleh dapat dikomparasikan dengan nilai \% T pada hasil analisis citra komet dengan menggunakan perangkat lunak pengolahan citra (20). Analisis semi kuantitatif lainnya adalah dengan menghitung nilai indeks kerusakan genetik (Genetic Damage Index). Seperti halnya analisis manual citra komet dikategorikan menjadi lima tipe yaitu tipe 0 yaitu pada sel yang tidak mengalami kerusakan hingga tipe IV pada sel dengan kerusakan tinggi. Indeks kerusakan genetik (GDI) kemudian dihitung dengan persamaan berikut (20).

GDI $=\frac{(\text { TipeI }+(2 \times \text { TipeII })+(3 \times \text { Tipe III })+(4 \times \text { TipeIV }))}{(\text { Tipe } 0+I+I I+I I I+I V)}$
Tes komet sangat sensitif untuk mendeteksi 100 hingga beberapa ribu patahan (breaks) dari setiap sel manusia yang terekspresikan sebagai \% T. Penelitian memperlihatkan bahwa terdapat hubungan yang hampir linier antara jumlah breaks dengan peningkatan dosis radiasi mulai dari 0 hingga $10 \mathrm{~Gy}$. Kurva yang menggambarkan hubungan antara dosis radiasi pengion dengan besarnya \% $\mathrm{T}$ dapat digunakan untuk mengkonversi hasil analisis citra komet menjadi jumlah lesions per $10^{6}$ pasangan basa DNA (Gambar 3) (19). Berdasarkan penelitian diketahui bahwa dosis radiasi sinar Gamma sebesar 1 Gy dapat menginduksi 0,29 patahan pada untai DNA (strand breaks) per $10^{9}$ Dalton DNA (22). Massa 1 pasangan basa (bp) adalah sebesar $650 \mathrm{Da}(21)$.

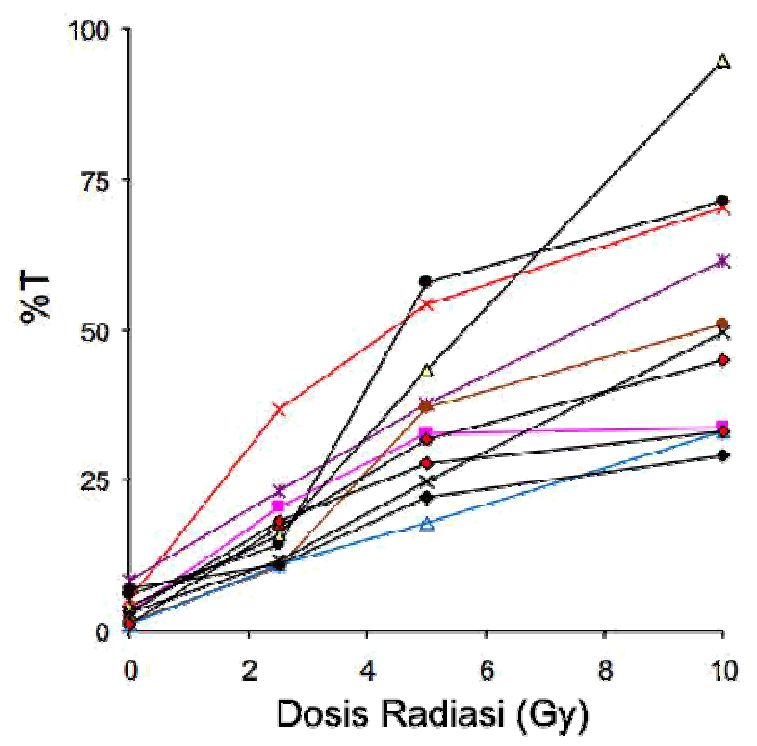

Gambar 3. Kurva yang menggambarkan hubungan antara dosis radiasi pengion dengan besarnya \% $\mathrm{T}$ dari 12 laboratorium yang berbeda (25). 
Tingkat kemiringan (slopes) pada kurva kalibrasi dapat diguna-kan untuk menghitung jumlah kerusakan (lesions) per $10^{6}$ bp berdasarkan \% DNA ekor pada komet dengan persamaan berikut (22).

Jumlahlesions $/ 10^{6}$ bp $=\frac{\text { \% DNA ekor }}{\text { Nilai keminimgan kurva kalibras! }} \times \frac{0,29}{10^{9}} \times 650 \times 10^{6}$

Laboratorium yang menggunakan teknik tes komet untuk mengetahui tingkat kerusakan DNA sangat disarankan memiliki kurva kalibrasi hubungan dosis radiasi pengion dengan besarnya \% T. Kurva tersebut dapat digunakan untuk mengkonversi hasil analisis citra komet menjadi jumlah lesions per $10^{6}$ pasangan basa (bp) DNA. Dosis yang digunakan dalam pembuatan kurva dapat berkisar antara 0 hingga $10 \mathrm{~Gy}$. Apabila laboratorium tidak memiliki peralatan untuk melakukan analisis citra komet dengan perangkat lunak pengolahan citra maka analisis dapat dilakukan secara manual. Seperti telah dijelaskan sebelumnya analisis secara manual sebaiknya dilakukan pada 100 komet sehingga diperoleh nilai analisis manual dalam kisaran 0 sampai 400. Nilai analisis manual kemudian dibagi empat sehingga diperoleh kisaran nilai 0 hingga 100 yang dapat dikomparasikan dengan nilai $\% \mathrm{~T}$.

\section{VARIASI HASIL ANALISIS TES KOMET}

Variasi pada hasil tes komet merupakan permasalahan yang penting untuk diperhatikan. Variasi dapat terjadi antara beberapa percobaan dalam satu laboratorium meski metode yang digunakan sama.
Variasi antar laboratorium dapat dipastikan akan terjadi mengingat metode yang digunakan tidaklah sama. Beberapa usaha telah dilakukan secara ekstensif oleh peneliti di dunia untuk meminimalisasi variasi tersebut dengan menstandardisasi metode tes komet yang digunakan. Tahapan kritis pada tes komet kini telah diidentifikasi yaitu pada konsentrasi agarose yang digunakan, waktu inkubasi pada alkali dan kondisi elektroforesis (waktu, temperatur serta gradien volt-ase yang digunakan) (23).

Bahkan saat ketiga tahapan tersebut telah dikontrol variasi terkadang tetap terjadi. Alternatif lain adalah dengan menggunakan standard acuan pada penelitian yaitu sel dengan tingkat kerusakan DNA yang telah diketahui secara pasti. Paparan sinar $X$ dengan dosis tertentu atau pemberian $\mathrm{H}_{2} \mathrm{O}_{2}$ pada konsentrasi yang diketahui secara pasti dapat dilakukan untuk membuat sel standard acuan. Penggunaan standard acuan sangat berguna saat melakukan penelitian berkelanjutan dalam jangka panjang untuk mengetahui konsistensi metode yang digunakan (23).

Idealnya sel standard acuan harus diletakkan dalam gel yang sama dengan sel sampel. Masalah yang timbul kemudian adalah bagaimana membedakan sel standard acuan dengan sel sampel setelah proses elektroforesis dan pewarnaan selesai dilakukan. Hingga kini terdapat beberapa cara untuk membedakan sel standard acuan dengan sel sampel, meskipun sel standard acuan tidak belum digunakan secara rutin pada laboratorium tes komet. Identifikasi sel standard acuan dapat dilakukan dengan 
penggunaan bromodeoxyuridine (BrdU)

yang dapat terinkorporasi kedalam timidin pada DNA untuk kemudian diwarnai dengan pe-warna fluorescent. Sel standard acuan dan sel sampel kemudian dibedakan dengan mengunakan filter yang berbeda pada mikroskop fluorescenct. Metode lainnya adalah dengan menggunakan sel dari orga-nisme yang berbeda misalnya sel eritrosit ikan. Sel standard acuan yaitu sel eritrosit ikan akan dengan mudah dapat dibedakan dengan sel sampel yaitu sel limfosit darah tepi manusia karena memiliki bentuk yang berbeda (23).

Penggunaan sel standard acuan sebagai kontrol positif dan sel tanpa perlakuan sebagai kontrol negatif dalam suatu penelitian sangat disarankan. Hingga kini belum terdapat konsensus mengenai sumber yang digunakan dalam membuat sel standard acuan. Paparan radiasi pengion memiliki kelebihan bila digunakan dalam membuat sel standard acuan yaitu dapat diketahui secara pasti jumlah breaks pada DNA dengan bantuan kurva kalibrasi hubungan dosis radiasi pengion dengan besarnya \% T (24). Secara prinsip konversi hasil analisis tes komet sebagai nilai frekuensi patahan (breaks) DNA menggunakan kurva kalibrasi hubungan dosis radiasi pengion dengan besarnya $\% \mathrm{~T}$ adalah salah satu cara agar hasil tes komet antar penelitian dapat dibandingkan. Akan tetapi konversi tersebut bukan tanpa masalah mengingat banyak peneliti tidak memiliki akses ter hadap sumber radiasi sehingga sulit untuk memiliki kurva kalibrasi sendiri. Bahkan saat sumber radiasi tersedia dan memungkinkan untuk memiliki sel standard acuan dengan pemberian paparan radiasi pada dosis tertentu masih terdapat aspek yang harus diperhatikan. Metode tes komet yang digunakan pada sel standard acuan dan sel sampel tidak akan pernah sama seratus persen (23).

Hingga kini beberapa usaha telah dilakukan oleh konsorsium ECVAG (European Comet assay Validation Group) untuk mengetahui secara pasti variasi yang timbul serta penyebabnya pada hasil tes komet. Percobaan pertama dilakukan dengan melibatkan 12 laboratorium di Eropa (25). Percobaan kedua dilakukan dengan melibatkan 10 laboratorium (26). Variasi antar laboratorium umumnya disebabkan oleh perbedaan metode tes komet yang digunakan. Variasi yang terjadi dapat dikurangi apabila hasil akhir analisis dikonversi menjadi nilai frekuensi patahan (breaks) DNA menggunakan kurva kalibrasi hubungan dosis radiasi pengion dengan besarnya \% T. Percobaan ketiga dilakukan dengan tujuan untuk mengimplementasikan metode standard tes komet agar mengurangi variasi yang akan timbul. Sayangnya beberapa laboratorium mengalami kesulitan untuk mengadopsi metode tersebut (27). Percobaan keempat dilakukan untuk mengidentifikasi faktor penyebab variasi dan disimpulkan bahwa masih sulit mengidentifikasi secara pasti penyebab terbentuknya variasi antar laboratorium (28). Meskipun demikian secara garis besar seperti telah dijelaskan sebelumnya bahwa tahapan kritis pada tes komet adalah pada konsentrasi agarose yang digunakan, waktu inkubasi pada alkali dan kondisi elektroforesis (waktu, temperatur serta gradien voltase yang digunakan). 
Komet akibat paparan radiasi pengion terutama dipengaruhi oleh waktu elektroforesis dan gradien voltase elektroforesis yang digunakan. Waktu elektroforesis bervariasi hingga paling lama selama 40 menit sedangkan gradien voltase umumnya sebesar 0,2 hingga 1,6 V/cm. Pengukuran gradien voltase elektroforesis yang digunakan harus dilakukan dengan meletakkan slide berada diantara elektroda karena lokasi tersebut adalah lokasi dimana potensial elektrik menarik DNA yang mengalami kerusakan keluar dari nukleus. Penghitungan nilai gradien voltase elektroforesis $(\mathrm{V} / \mathrm{cm})$ dapat dilakukan dengan bantuan lembar kerja Microsoft Excel yang bisa diunduh pada alamat berikut http://comics. vitamib.com/electrophoresis-physics.

Secara umum proses elektroforesis direkomendasikan untuk dilakukan dalam lemari pendingin sehingga temperatur pada solusi dan gel tidak meningkat hingga melebihi $15{ }^{\circ} \mathrm{C}$. Penelitian McKelvey-Martin et al. (1993) memperlihatkan bahwa terdapat sedikit perbedaan pada komet yang terbentuk dengan melakukan elektroforesis pada $5{ }^{\circ} \mathrm{C}$ atau $10^{\circ} \mathrm{C}$. Sel yang digunakan dalam penelitian tersebut adalah sel limfosit yang diradiasi dan tidak diradiasi (29). Peningkatan yang signifikan pada migrasi DNA terjadi saat elektroforesis dilakukan pada temperatur tinggi (mencapai $25^{\circ} \mathrm{C}$ ). Hasil penelitian tersebut dikonfirmasi oleh penelitian Sirota et al. (2014) yang membandingkan antara elektroforesis pada temperatur $4{ }^{\circ} \mathrm{C}$ dan $20^{\circ} \mathrm{C}$ (30).

Secara keseluruhan kondisi yang direkomendasikan adalah menggunakan konsentrasi akhir agarose sebesar 0,6 hingga $0,8 \%$, lama waktu inkubasi alkali lebih kurang 40 menit dan elektroforesis dilakukan selama 20 hingga 30 menit dengan gradien voltase sebesar lebih kurang $1 \mathrm{~V} / \mathrm{cm}$. Kondisi apapun yang digunakan harus dilakukan secara seksama dan cermat serta dilaporkan dalam publikasi agar dapat dilakukan komparasi dengan laboratorium lain (23). Hingga kini masih terdapat perdebatan mengenai parameter utama yang paling relevan untuk digunakan dalam analisis komet. Panjang ekor komet kini tidak banyak lagi digunakan oleh para peneliti. Parameter \% T terutama pada sel limfosit darah tepi lebih banyak digunakan terutama dalam studi biomonitoring sebagai parameter akhir analisis komet. Perdebatan mengenai penggunaan \% $\mathrm{T}$ atau momen ekor sebagai parameter akhir analisis komet telah mengaburkan masalah yang sebenarnya yaitu apakah parameter akhir dalam analisis komet dapat berguna bagi peneliti yang tidak terbiasa dengan tes komet. Penelitian dengan menggunakan limfosit darah tepi pada studi biomonitoring manusia parameter akhir berupa \% T dianggap lebih menguntungkan dan lebih banyak digunakan oleh para peneliti lainnya (24).

\section{KESIMPULAN}

Tes komet dapat digunakan untuk mengetahui tingkat kerusakan DNA. Beberapa hal perlu dilakukan untuk meningkatkan keakuratan analisis hasil tes komet serta mendapatkan hasil yang konsisten dan mencegah variasi yang akan timbul. Pertama perlu dibuat kurva kalibrasi 
yang menggambarkan hubungan antara dosis radiasi pengion dengan besarnya $\% \mathrm{~T}$. Kurva tersebut dapat digunakan untuk mengkonversi hasil analisis citra komet menjadi jumlah lesions per $10^{6}$ pasangan basa DNA. Kedua perlu dilakukan penghitungan gradien voltase elektroforesis yang digunakan dalam tes komet. Gradien voltase yang disarankan untuk digunakan dalam tes komet adalah sebesar $1 \mathrm{~V} / \mathrm{cm}$. Ketiga perlu dipertimbangkan penggunaan sel standard acuan yaitu dengan sel eritrosit ikan atau dengan penggunaan BrdU pada sel limfosit tepi manusia sehingga dapat dibedakan dengan sel sampel saat menganalisis hasil tes komet. Terakhir penggunaan perangkat lunak pengolahan citra untuk menganalisis hasil tes komet harus dilakukan untuk meningkatkan akurasi dan presisi serta mengurangi subjektivitas dalam menganalisis citra komet.

\section{DAFTAR PUSTAKA}

1. Alatas $Z$, Lusiyanti $Y$, Purnami $S$, Ramadhani $D$, Lubis $M$, Suvifan VA. Respon Sitogenetik Penduduk Daerah Radiasi Alam Tinggi di Kabupaten Mamuju, Sulawesi Barat. Jurnal Sains dan Teknologi Nuklir Indonesia 2012;13(1):13-26.

2. Alatas Z. Ketidakstabilan Genom Akibat Radiasi. Prosiding Presentasi IImiah Keselamatan Radiasi dan Lingkungan XI, Jakarta: Penerbit PTKMR;2006.

3. Nandhakumar $\mathrm{S}$, Parasuraman $\mathrm{S}$, Shanmugam MM, Ramachandara RK, Parkash C, Vishnu BB. Evaluation of DNA damage using single-cell gel electrophoresis (Comet Asay). Journal of Pharmacology and

Pharmacotherapeutics2011;2(2):107111.

4. Langie SAS, Azqueta A, Collins AR. The comet assay: past, present, and future. Frontiers in genetics2015;6(266):6-8.

5. Azqueta A, Slyskova J, Langie SAS, Gaivão IO, Collins A.Comet assay to measure DNA repair: approach andapplications. Frontiers in genetics 2014;5(288):71-78.

6. Ersson C, Moller L. The effects on DNA migration of altering parameters in the comet assay protocol suchas agarose density, electrophoresis conditions and durations of the enzyme or thealkaline treatments.Mutagenesis 2011;26(6):689-695.

7. Lovell DP, Omori T. (REVIEW) Statistical issues in the use of the comet assay. Mutagenesis 2008;23(3):171-182.

8. CellBiolabs, Inc. Comet Assay Kits, 3Well (Internet). Cell Biolabs, Inc; (cited 2016 Feb 28). Available from: http://www.cellbiolabs.com/cometassay-kits-3-well

9. Collins A.The Comet Assay (Principles, Applications, and Limitations). InDidenko VV editor. In Situ Detection of DNA Damage (Methods and Protocols), 1st ed.New York: Humana Press;2002.

10. Azqueta A, Meier S, Priestley $C$, Gutzkow KB, Brunborg G, SalletteJ, et al. The influence of scoring method on variability in results obtained with the comet assay. 
Mutagenesis2011;26(3):393-399.

11. Lehnert S.Biomolecular Action of lonizing Radiation.New York (NY):

Taylor \& Francis Group; 2007.

12. Lovell DP.Statistical Analysis of Comet Assay Data. In Dhawan A, Anderson D editors. The Comet Assay in Toxicology.Cambridge:The Royal Society of Chemistry; 2009.

13. Garcia O, Romero I, Gonzalez JE, Moreno DL, Cuetara E, Rivero Y,et al. Visual estimation of the percentage of DNA in the tail in the comet assay: Evaluation of different approaches in an intercomparison exercise. Mutation Research 2011;720:14-21.

14. Helma C, Uhl M. A public domain image-analysis program for the singlecell gel-electrophoresis comet assay. Mutation Research2000;466:9-15.

15. Collins TJ. ImageJ for microscopy. BioTechniques2007;43:S25-S30.

16. Putra D. Pengolahan Citra Digital. Yogyakarta:Andi Press;2010.

17. Konca K, Lankoff A, Banasik A, Lisowska H, Kuszewski T, Gozdz S, et al. A cross-platform public domain PC image-analysis program for the comet assay. Mutation Research2003;534:1520.

18. González JE, Romero I, Barquinero JF, García O. Automatic Analysis of Silverstained Comets by CellProfiler Software. Mutation Research 2012;748:60-64.

19. Collins AR, Oscoz AA, Brunborg G, Isabel-Gaiva o I, Giovannelli L, MarcinKruszewski M,et al. The Comet assay:topical issues.
Mutagenesis2008;23:143-151.

20. Mohammadi S, Taghavi-dehaghani M, Gharaati MR, Masoomi R, GhiassiNejad M. Adaptive Response of Blood Lymphocytes of Inhabitants Residing in High Background Radiation Areas of Ramsar- Micronuclei , Apoptosis and Comet Assays. Journal of Radiation Research 2006;47(3-4):279-85.

21. Ahnström G, Erixon K.Measurement of strand breaks by alkaline denaturation and hydroxyapatite chromatography.In Friedberg EC, Hanawalt PC editors. DNA Repair: A Laboratory Manual of Research Procedures. New York: Marcel Dekker;1981.

22. Kohn KW, Erickson LC. Ewig RA, Friedman CA.Fractionation of DNA from mammalian cells by alkaline elution.Biochemistry 1976;15:4629_ 4637.

23. Collins AR, Yamani NE, Lorenzo Y, Shaposhnikov S, Brunborg G, Azqueta A. Controlling variation in the comet assay. Frontiers in Genetic 2014;5(359):1-6.

24. Møller P, Loft S, Ersson C, Koppen G, Dusinska M, Collins A. On the search for an intelligible comet assay descriptor. Frontiers in Genetic 2014;5(217): 1-4.

25. Forchhammer L, Johansson $C$, Loft $S$, Moller L, Godschalk RWL, Langie SAS, et al. Variation in the measurement of DNA damage by comet assay measured by the ECVAG interlaboratory validation trial. Mutagenesis2010;25(2):113-123. 
26. Johansson C, Moller P, Forchhammer L, Loft S, Godschalk RWL, Langie SAS, et al. An ECVAG trial on assessment of oxidative damage to DNA measured by the comet assay. Mutagenesis2010;25(2):125-132.

27. Forchhammer L, Ersson C, Loft S, Moller L, Godschalk RWL, Schooten FJ,et al.Inter-laboratory variation in DNA damage using a standard comet assay protocol. Mutagenesis2012;27(6):665-672.

28. Ersson $\mathrm{C}$, Møller $\mathrm{P}$, Forchhammer $\mathrm{L}$, Loft S, Azqueta A, Godschalk RWL, et al. An ECVAG inter-laboratory validation study of the comet assay: inter-laboratory and intra-laboratory variations of DNA strand breaks and FPG-sensitive sites in human mononuclear cells. Mutagenesis 2013;28(3):279-286.

29. McKelvey-Martin VJ, Green MHL, Schmezer P, Pool-Zobel BL, deMéo MP, Collins AR. The single cell gel electrophoresis assay(comet assay): a European review. Mutation Research1993;288:47-63.

30. Sirota NP, Zhanataev AK, Kuznetsova EA, Khizhnyak EP, AnisinaEA, Durnev AD. Some causes of inter laboratoryvariation in the results of comet assay. Mutation Research2014; 770:16-22. 
Jurnal Sains dan Teknologi Nuklir Indonesia

Indonesian Journal of Nuclear Science and Technology

Vol. 17, No 1, Februari 2016; 37-48

ISSN 1411 - 3481 